\begin{abstract}
Iranica
Abstracta Iranica Revue bibliographique pour le domaine irano-aryen

Volume 42-43 | 2021

Comptes rendus des publications de 2019-2020
\end{abstract}

\title{
Anne Démy-Geroe. Iranian National Cinema: The Interaction of Policy, Genre, Funding, and Reception
}

\section{Max Bledstein}

\section{(2) OpenEdition}

1 Journals

\section{Electronic version}

URL: https://journals.openedition.org/abstractairanica/52950

DOI: 10.4000/abstractairanica.52950

ISSN: 1961-960X

Publisher:

CNRS (UMR 7528 Mondes iraniens et indiens), Éditions de l'IFRI

\section{Electronic reference}

Max Bledstein, "Anne Démy-Geroe. Iranian National Cinema: The Interaction of Policy, Genre, Funding, and Reception", Abstracta Iranica [Online], Volume 42-43 | 2021, document 3, Online since 30 July 2021, connection on 14 December 2022. URL: http://journals.openedition.org/abstractairanica/52950 ; DOI: https://doi.org/10.4000/abstractairanica.52950

This text was automatically generated on 14 December 2022.

All rights reserved 


\title{
Anne Démy-Geroe. Iranian National Cinema: The Interaction of Policy, Genre, Funding, and Reception
}

\author{
Max Bledstein
}

\section{REFERENCES}

Anne Démy-Geroe. Iranian National Cinema: The Interaction of Policy, Genre, Funding, and Reception. Abingdon \& New York: Routledge, 2020, 222p. (Iranian Studies). ISBN 978-0367219413

1 This book offers a thoughtful and useful exploration of the production and distribution of Iranian cinema both within and beyond the country. Démy-Geroe draws on her own experience as artistic director of the Brisbane International Film Festival, which led her to annual trips to Tehran's Fajr International Film Festival. These visits gave her the opportunity to meet with a number of Iran's most established filmmakers and industry insiders (including both government officials and employees such as sales agents), interviews with whom she references throughout the book. The discussion of these sources and various others focuses on the years 2000-2013, which allows for a comparison between the second half of the presidency of Mohammad Khatami (1997-2005) and that of Mahmoud Ahmadinejad (2005-2013). Démy-Geroe organizes the six chapters that examine this time period into three primary clusters: one on genres and categories recognised by the government, one on international reception of Iranian cinema, and one on increases in government control of film following Ahmadinejad's 2009 re-election.

2 These sections provide a comprehensive look at the creation and reception of Iranian films during the years in question. Démy-Geroe's unique professional and personal position makes the book especially valuable, as she provides a level of insight into distribution and production rarely found in English-language scholarship on Iranian 
cinema. Scholars looking to learn more about a crucial period in the country's robust and vibrant film history will find much of note in this engaging and insightful study.

\section{AUTHORS}

\section{MAX BLEDSTEIN}

University of New South Wales 